\title{
New Limboconjunctival Flap Technique in the Surgical Treatment of Primary Pterygium: A Preliminary Report
}

\author{
Fadime Nuhoğlu' 1 , Fatma Esin Özdemir², Kübra Sarıcı², Dilek Abul ${ }^{2}$ \\ ${ }^{1}$ Gelişim University Health Vocational High School, İstanbul, Turkey \\ ${ }^{2}$ Clinic of Eye Diseases, İstanbul Training and Research Hospital, İstanbul, Turkey
}

\begin{abstract}
Objective: To present our innovative limboconjunctival flap technique in the surgical treatment of primary pterygium and evaluate its effectiveness and safety.

Methods: Thirty three eyes of 32 patients diagnosed with primary pterygium were included in this study. Cases with primary pterygium extending $\geq 3$ $\mathrm{mm}$ into the cornea were analyzed in this prospective study. Patients with recurrent pterygium, double-head pterygium, and suspected malignity cases were excluded. A limboconjunctival flap prepared from the upper nasal conjunctiva adjacent to the area of excision was pulled over the scleral bed and fixed with three separated 8.0 vicryl sutures.
\end{abstract}

Results: Fifteen of the patients (46.87\%) were male and 17 were female (53.1\%). The mean age of the patients was 47.9 (42-69) years. No intraoperative complication was observed. The mean postoperative follow-up period was 5.2 months (1-6 months). In all cases, the corneal epithelial defect improved within a week. Ten (76.9\%) cases were successfully repaired, while in one case, the flap was displaced $0.5 \mathrm{~mm}$ toward the cornea. In addition, two recurrences were observed.

Conclusion: We suggest that our innovative technique can be an alternative approach in the surgical management of primary pterygium because of its easy practicability, rapid postoperative rehabilitation, and improved patient satisfaction. However, larger-scale comparative studies are required to establish the effectiveness and safety of this technique. (JAREM 2015; 5: 17-21)

Keywords: Flap, cornea, limboconjunctival, pterygium

\section{INTRODUCTION}

A pterygium is a triangular tissue situated in the interpalpebral region; its cap is on the cornea side, and it consists of three partsa body connected to the bulbar conjunctiva, a head that is advancing over the cornea, and the cap (1).

Although the etiopathogenesis of pterygium is not precisely known, many scientists believe that solar ultraviolet (UV) radiation is responsible for the development and progression of pterygium. Other factors that are blamed in the pathogenesis of pterygium are heat, micro traumas due to dust particles, a dry atmosphere, viral infections, immunological mechanisms, extracellular matrix remodeling, growth factors, some cytokines, antiapoptotic mechanisms, and a few angiogenic factors (2-4).

Because of the hyperplasia that occurs in the damaged limbal cells of those exposed to UV radiation, limbus tissue is perceived by the body as a foreign object, and chronic inflammation develops against this as a hypersensitivity reaction. This chronic inflammation, in turn, causes vascularization $(5,6)$.

The treatment of pterygium is symptomatic until a surgical indication is set. The definitive treatment after pterygium occurs is surgery (7-8). Desmarres stated in 1855 that after a pterygium was separated, it was transplanted by suturing to the fornix and then it underwent atrophy. This transplantation application of Desmarres pioneered all subsequent transplantation techniques developed to date (9). One of the main goals of a success- ful pterygium surgery is to avoid relapse. To date, many surgical approaches have been presented to find ways to cope with relapse. In recent years, conjunctival flaps and autografts have been generally preferred because of their higher success rates. Relapse rates are reported as $0-31 \%$ in conjunctival flaps and only $0-14.6 \%$ in autografts $(7,8)$. A limboconjunctival autograft is used in pterygium surgery with the aim to induce contact inhibition in abnormal residual tissue, to rearrange the limbal barrier with transplanted healthy limbal cells, and to construct a barrier against the invasion of the cornea by conjunctiva by preventing fibrosis (9). We developed this new flap technique to obtain an answer to the question of whether we can also establish this mechanism exactly in limboconjunctival flaps. In this study, we aimed to introduce the limboconjunctival flap technique that we newly developed for the surgical treatment of primary pterygium and to evaluate its efficiency and safety.

\section{METHODS}

Thirty-three eyes of 32 patients who were diagnosed with primer pterygium were retrospectively evaluated. Cases that had prier pterygium displaying $3 \mathrm{~mm}$ or more penetration into the cornea were included in the study. Cases with relapse pterygium, double-headed pterygium, and a suspicion of malignancy as well as cases with ocular surface disease and cases with less than 3 months follow-up were excluded from the study. Prior to the operation, the visual acuity of each patient was measured on a Snellen chart. Extension of pterygium onto the cornea was evaluated 
by conducting biomicroscopic evaluations. Intraocular pressure measurements were conducted by Goldman applanation tonometry. Preoperative symptoms of the cases were asked, recorded, and a scoring system was established by adding the number of symptoms present for each patient. This scoring is shown in Table 1.

\section{Surgical Technique}

A lip retractor was placed following appropriate surgical site cleaning. Topical proparacaine was dripped, and local anesthesia was established by lidocaine $20 \mathrm{mg} / \mathrm{mL}$ + epinephrine $\mathrm{HCl}$ $0.0125 \mathrm{mg} / \mathrm{mL}$ via a subconjunctival $26 \mathrm{G}$ needle. The conjunctiva and pterygium tissue were separated. Pterygium on the cornea surface was cleaned with a crescent knife. After performing pterygium excision on the patients, hemostasis was achieved on the scleral bed with monopolar cautery. Lidocaine $20 \mathrm{mg} / \mathrm{mL}+$ epinephrine $\mathrm{HCl} 0.0125 \mathrm{mg} / \mathrm{mL}$ were administered to the subconjunctival area via a $26 \mathrm{G}$ needle to ease the dissection in the upper nasal quadrant of the same eye. The limbus side of the scleral aperture was measured with the help of a Castroviejo caliper. A limboconjunctival flap large enough to cover the scleral aperture was separated from the tenon by performing a blunt dissection in the adjacent upper nasal area. The rectangular flap was thus prepared; its base being on the fornix. The limboconjunctival flap, prepared from the upper nasal conjunctiva adjacent to the excision area, was slid onto the scleral bed. The limbal lower corner of the flap was episclerally sutured to the lower limbus of the excision area. The upper corner of the flap was fixed to the upper limbus of the scleral aperture by a second episcleral suture. It was also fixed to the lower edge of the flap by a third episcleral suture. It was ensured that the limboconjunctival area of the flap corresponded to the limbus in the excision area. Suturation was not performed to the area that the flap was taken from (Figure 1). The sutures were removed from the cases in the $2^{\text {nd }}$ week. They were controlled on the $1^{\text {st }}$ day, $1^{\text {st }}$ week, $2^{\text {nd }}$ week, 1 st month, and then monthly. After the surgery, the eyes were shut until the corneas were epithelized. Postoperative topical antibiotic ofloxacin $5 \times 1$ was used. Topical steroid prednisolone acetate $4 \times 1$ was administered. Topical prednisolone acetate treatment was stopped on the second week to avoid its side effects such as glaucoma and cataract, and instead, a fluorometholone group steroid drip $4 \times 1$ was used for 2 months. A synthetic tear polyvinyl alcohol + povidone drip $5 \times 1$ and a synthetic tear gel carbomer $1 \times 1$ were used for 6 months.

In the controls, vision evaluation via a Snellen chart, biomicroscopic examinations, and intraocular pressure via Goldman applanation tonometry (GAT) were measured. The symptoms and complaints of patients were inquired again in the same way as they were prior to the operation, and their numbers were noted and a complaint score was formed after the operation.

Radial veins $1 \mathrm{~mm}$ or above in the paracentral area of the cornea was accepted as a sign of a relapse. Postoperative complications and relapse developments were recorded. Relapse cases were accepted as a failure.

\section{RESULTS}

Thirty-three eyes of 32 patients were included in the study. Fifteen of the patients (46.87\%) were male and 17 (53.13\%) were female. The average age of the cases was 47.9 (42-69) years. When

\section{Table 1. Complaints score}

Complaints: burning, watering, itching, photophobia, feeling of a foreign object, rash

\begin{tabular}{|l|c|c|}
\hline Complaints & None & 0 \\
\hline $1-2$ & Mild & $1+$ \\
\hline $3-4$ & Moderate & $2+$ \\
\hline 5 and above & Severe & $3+$ \\
\hline
\end{tabular}

\section{Table 2. Demographic features of the cases}

\begin{tabular}{|l|c|c|}
\hline Gender & Age (mean) years & Laterality \\
\hline 15 male & & Right eye in 15 patients \\
\hline 17 female & $47.9(42-69)$ & Left eye in 18 patients \\
\hline
\end{tabular}

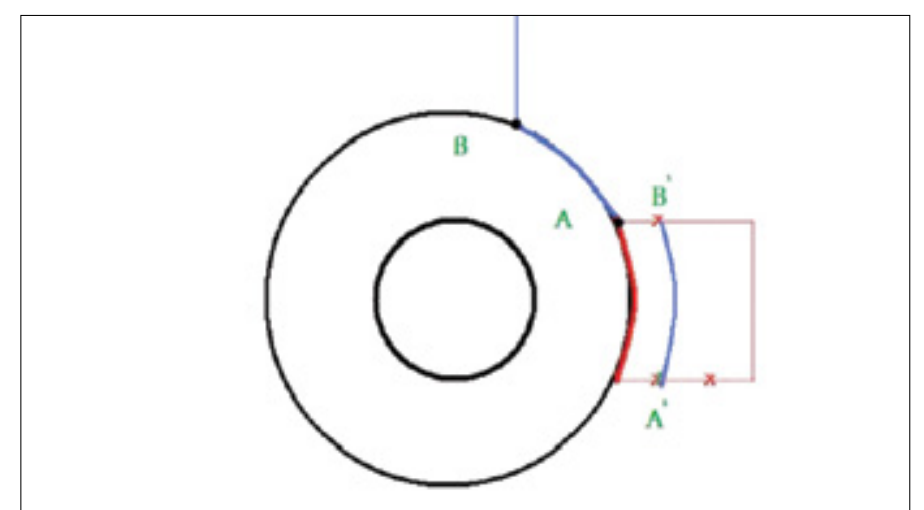

Figure 1. Schematic drawing of the technique B-A: Limboconjunctival flap, B'-A': Pterygium excision area; X: Episcleral suture locations

pterygium laterality was viewed, 15 patients had pterygium on the right eye, 18 on the left eye, and 1 had bilateral pterygium (Table 2).

On an average, 7.2 months (3-11 months) of postoperative follow-up was performed. No intraoperative complications were observed. The cornea epithelial defect was observed to close within a week in all cases. Avascular flap and dellen complications were not observed in any of the cases (Figure 2, 3). The flap was observed to cling on to the scleral bed in the 1st postoperative week. Thirty-one cases were successful (93.9\%), while the flap was observed to slide $0.5 \mathrm{~mm}$ onto the cornea in two cases. In these cases, the edge of the flap that slid onto the cornea was excised. In one case, granulation tissue formation was observed in the border of the graft, and it was excised. Acute inflammatory development was observed in the pathological diagnosis of the case. A relapse was not observed in our 3-month follow-up of this case.

A relapse was observed in two cases (6.1\%). The relapse was detected in the $2^{\text {nd }}$ month in one of these cases and in the $3 r d$ month in the other case. Pterygium excision and limboconjunctival autograft were performed on these cases 6 months after the initial surgery. A relapse was not observed in the, on an average, 4-month follow-up of these cases. When the postoperative 


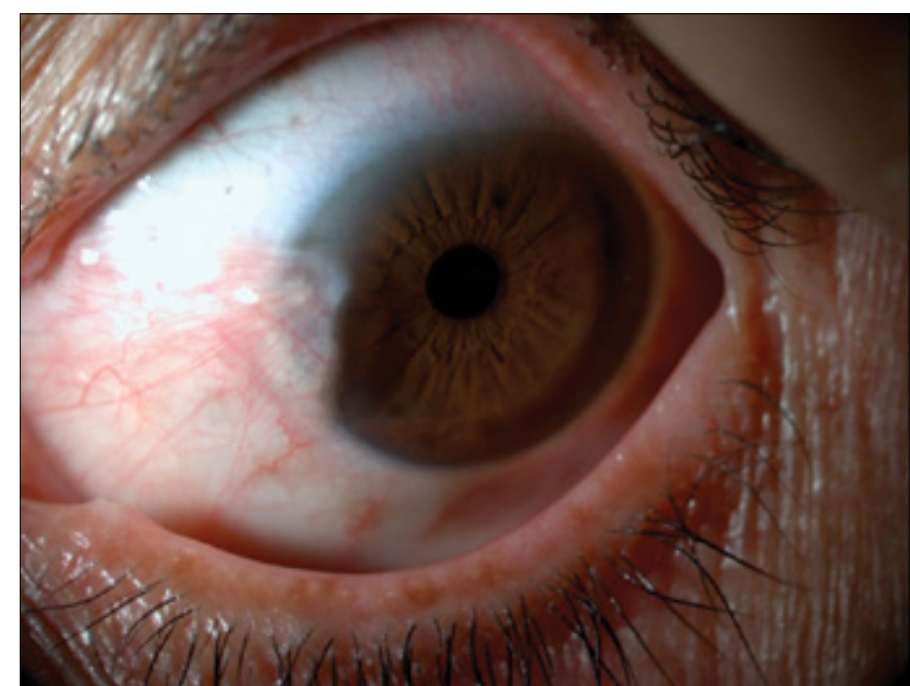

Figure 2. Preoperative pterygium

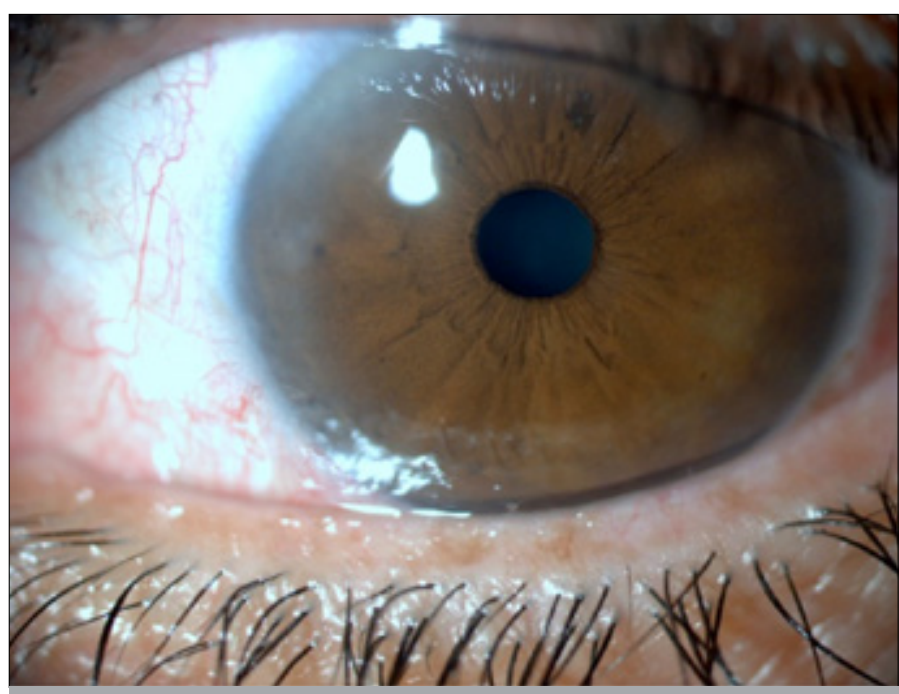

Figure 3. Postoperative image of a case that underwent a limboconjunctival flap operation

complaint scoring is viewed, a significant decrease in complaints can be observed compared with the preoperative complaints $(p<0.05)$.

\section{DISCUSSION}

Although extremely different surgical approaches are presented and the present methods have been improved to find ways to cope with relapse, success in this area is still limited (1).

With the conjunctival flap technique, which is one of the techniques studied, one attempts to establish a healthy conjunctiva by sliding the flaps or pedunculated flaps from the surrounding tissue. The standard technique of pterygium transplantation began with the technique of McReynolds. In this technique, the excised pterygium is sutured to the lower subconjunctival area, and the remaining conjunctival aperture is sutured with a 4/0 silk suture. In Neher's technique, however, the head of the pterygium is embedded to the superior and sutured to the episclera. Knapp's technique is generally used in very wide pterygia. Knapp peeled pterygium from the cornea, bisected it with a horizontal cut, and sutured half of the flap to above the conjunctival arc and half to below. Blaskovic modified this technique and sutured to the episclera. In Terson's technique, however, Terson performed a vertical incision parallel to the lower border of the quadrilateral defect that resulted after the total excision of the pterygium, slid the flap upwards, and then sutured it. In Arlt's technique, Arlt totally excised the pterygium and closed the defect with the flap that he had slid from under. Czermark defined another technique; by performing paracorneal incisions above and below, Czermark created small flaps and sutured them together (1).

In 1985, after the study that Kenyon et al. (10) conducted on 17 cases, the use of conjunctival autografts became popular. In this study, Kenyon reported a relapse rate of $5.3 \%$. After considering that the UV light-based limbal cell loss could cause pterygium formation, limbus has started to be added to the conjunctival autograph. This limboconjunctival autograft technique aims at inducing contact inhibition in the abnormal residual tissue, a rearranging of the limbal barrier with transplanted healthy limbal cells, and, as a result, construction of a barrier against the invasion of the cornea by conjunctiva by preventing fibrosis.

Ayala et al. (11) used bioadhesives in conjunctival autographs and reported a relapse rate of $4.54 \%$. Dupps et al. (12) reported in their study that in narrow-strip conjunctival autografts, $94.7 \%$ of the cases were successful. Luanratanakorn et al. (13) compared amniotic membrane and conjunctival autographs in their study, and in the primary pterygium group, the conjunctival autographs showed a $12.3 \%$ recurrence rate, whereas the amniotic group showed $25 \%$, and in the relapse pterygia, the conjunctival autographs showed a $21.4 \%$ relapse rate, whereas amniotics showed $52.6 \%$. In a comparative study consisting of four groups by Alpay et al. (14), a bare sclera technique, bare sclera + mitomycin $C$, a conjunctival flap technique, and a conjunctival autograph technique were compared. The recurrence rate was observed as $38.09 \%$ in the bare sclera group, as $25 \%$ in the bare sclera + mit C group, as $33.3 \%$ in the conjunctival flap group, and as $33.3 \%$ in the conjunctival autograph group. Hall et al. (15) compared tissue adhesive and vicryl in conjunctival autographs and observed a $0 \%$ recurrence rate in the tissue adhesive group and $8 \%$ in the vicryl group. In a study performed by Güler et al. (16), a 13.3\% recurrence rate was reported in the limbal-conjunctival autografts of cases with relapse pterygium who were younger than 40 years old. Lei (17) reported a $1.6 \%$ recurrence rate in conjunctival pedunculated flap surgery. Alp et al. (18) reported a rotational conjunctival flap recurrence rate as $1.6 \%$. Jap et al. (19) reported a rotational conjunctival flap recurrence rate of $4 \%$. McCombes et al. (20) performed conjunctival flaps on 258 cases with primary pterygium. They followed $86 \%$ of them for at least 1 year and reported a recurrence rate of $3.2 \%$. They did not observe complications; however, they observed a poor cosmetic appearance due to a rotation tissue. An acceptable level of cosmetic appearance was established after a certain period of time. They argue that conjunctival flap tissue prevents the development of recurrence by causing a change in limbal cells. Eksteen et al. (21) compared primary suturation and rotational flap closing. They reported recurrence rates of $66.7 \%$ in primary suturation and $20.7 \%$ in the rotational conjunctival flap technique. Uçakhan et al. (22) per- 


\section{Table 3. Comparative literature results}

\begin{tabular}{|l|l|l|}
\hline Conjunctival flap & Conjunctival autograft & $\begin{array}{l}\text { Limbal-conjunctival } \\
\text { autograph }\end{array}$ \\
\hline $1.6 \%$ & $4.54 \%$ & $7.40 \%$ \\
\hline Lei 1996 & Ayala et al. 2008 & Ivekovic 2001 \\
\hline $33.3 \%$ & $33.3 \%$ & $1.9 \%$ \\
\hline Alpay et al. 2009 & Alpay et al. 2009 & Young 2004 \\
\hline $3.2 \%$ & $12.3 \%$ & $0 \%$ \\
\hline McCombes 1994 & Luanratanakorn 2006 & Gris 2000 \\
\hline 20.7\% & 5.3\% & $13.3 \%$ \\
\hline Eksteen et al. 2010 & Dupps et al. 2007 & Güler et al. 1999 \\
\hline 0\% & $22.2 \%$ & $14.6 \%$ \\
\hline Uçakhan et al. 2006 & Manning et al. 1997 & Mutlu et al. 1999 \\
\hline 16.6\% & 4.76\% & $5.6 \%$ \\
\hline Alp et al. 2003 & Tannavuvat and & Hyun Ho Kim 2008 \\
\hline
\end{tabular}

formed symmetric conjunctival flap transposition to a total of 43 eyes and did not observe recurrence in any of the cases.

It is maintained that in high-risk groups, limbal transplantation is safer and more effective than conjunctival autograft transplantation in avoiding relapse in advanced and recurrent pterygium (23).

In recent years, publications that mention the limbal stem cell deficiency theory in pterygium etiopathogenesis have been reported. Limbal stem cells prevent the invasion of the cornea by conjunctival epithelial cells by acting like a barrier and form the source of cornea epithelia. Furthermore, flaps hold on to where they are carried quicker than grafts do and thus wound healing occurs quicker. Based on this theory, we contemplated that if the flap was simultaneously limboconjunctival, it would reduce relapses even more, and hence, we applied this new technique of ours to 33 eyes. The two cases (6.1\%) that relapsed were among the first patients that we applied the technique to. We maintain that the failure in these cases resulted from a lack of surgical experience.

Relapse rates in pterygium following limbal stem cell or limboconjunctival tissue transplantation vary between $0 \%$ and $14.6 \%$ (23-27). Conjunctival autograph relapse rates vary between $0 \%$ and $33.3 \%$ in the literature $(11-14,28,29)$. Relapse rates after amniotic membrane coverage are reported to be between $3.0 \%$ and $40.9 \%(13,27,28,30)$. Relapse rate in pedunculated flaps is reported to be $10.7 \%$ and $0-33.3 \%$ in sliding flaps (Table 3) (14, $17,18,20-22)$.

\section{CONCLUSION}

We maintain that the limboconjunctival sliding flap technique that we have developed is successful, safe, and effective because of its ease of use, non-obstruction of filtration surgery, and quicker application times compared with autografts, and it also has low relapse rates. However, large-scale, comparative, and longterm follow-up studies are needed.
Ethics Committee Approval: Ethics committee approval was received for this study from the ethics committee of Istanbul Training and Research Hospital.

Informed Consent: Written informed consent was obtained from patients who participated in this study.

Peer-review: Externally peer-reviewed.

Author contributions: Concept - F.N.; Design - F.N., F.E.Ö.; Supervision - F.N.; Resource - F.N., F.E.Ö.; Materials - F.N.; Data Collection and/or Processing - F.E.Ö.; Analysis and/or Interpretation - F.N.; Literature Search - F.N., F.E.Ö.; Writing - F.N., F.E.Ö.; Critical Reviews - F.N.

Conflict of Interest: No conflict of interest was declared by the authors.

Financial Disclosure: The authors declared that this study has received no financial support.

\section{REFERENCES}

1. Agarwal S, Agarwal A, Apple DJ, Buratto L, Alio JL, Pandey SK, Agarwal Amar. External eye diseases. Textbook of ophthalmology. 2002; section F: 862-71.

2. Kaufman HE. Pterygıum. In:Kaufman HE (ed) Companion handbook to the cornea, 2nd edn. Butterworth-Heinemann, Woburn, pp 2000; 473-98.

3. Jaros PA, DeLuise VP. Pingueculae and pterygia. Surv Ophthalmol 1988; 33: 41-9. [CrossRef]

4. Adamis AP, Starck T, Kenyon KR. The management of pterygium. Ophthalmol Clin North Am 1990; 3: 611-23.

5. Coroneo MT. Pterygium as an early indicator of ultraviolet insolation: a hypothesis. Br J Ophthalmol 1993; 77: 734-9. [CrossRef]

6. Taylor HR, West S, Munoz B, Rosenthal FS, Bressler SB, Bressler NM. The long-term effects of visible ligth on the eye. Arch Ophthalmol 1992; 110: 99-104. [CrossRef]

7. Hirst LW. The treatment of pterygium. Surv Ophthalmol 2003; 48: 145-80. [CrossRef]

8. Lee JS, Oum BS, Lee SH. Mitomycin C influence on inhibition of celluler proliferation and subsequent synthesis of type I collegen and laminin in primary and recurrent pterygia. Ophthalmic Res 2001; 33: 140-6. [CrossRef]

9. Nabawi KS, Ghonim MA, Ali MH. Evalution of limbal conjunctival autogreft and low-dose mitomycin $C$ in the treatment of recurrent pterygium. Ophthalmic Surg Lasers Imaging 2003; 34: 193-6.

10. Kenyon KR, Wagoner MD, Hettinger ME. Conjunctival autograft transplantation for advanced and recurrent pterygium. Ophthalmology 1985; 92: 1461-70. [CrossRef]

11. Ayala M. Results of pterygium surgery using a biologic adhesive Cornea 2008; 27: 663-7.

12. Dupps WJ Jr, Jeng BH, Meisler DM. Narrow-strip conjunctival autograft for treatment of pterygium. Ophthalmology 2007; 114: 227-31. [CrossRef]

13. Luanratanakorn P, Ratanapakorn T, Suwan-apichon O, Chuck RS. Randomised controlled study of conjunctival autograft versus amniotic membrane graft in pterygium excision. Br J Ophthalmol 2006; 90: 1476-80. [CrossRef]

14. Alpay $\mathrm{A}$, Uğurbaş $\mathrm{SH}$, Erdoğan B. Comparing techniques for pterygium surgery. Clin Ophthalmol 2009; 3: 69-74.

15. Hall RC, Logan AJ, Wells AP. Comparison of fibrin glue with sutures for pterygium excision surgery with conjunctival autografts. Clin Experimental Ophthalmol 2009; 37: 584-9. [CrossRef]

16. Güler M, Sobacı G, ilker S. Limbal-conjunctival autograft transplantation in cases with recurrent pterygium. Acta Ophthalmol 1994; 72 : 721-6. [CrossRef]

17. Lei G. Surgery for pterygium using a conjunctival pedunculated flap slide. Br J Ophthalmol 1996; 80: 33-4. [CrossRef]

18. Alp BN, Yanyali A, Ay GM, Keskin O. Conjunctival rotation autograft for primary pterygium. Ophthalmologica 2003; 217: 454. [CrossRef] 
19. Jap A, Chan C, Lim L, Tan DT. Conjunctival rotation autograft for pterygium. An alternative to conjunctival autografting. Ophthalmology 1999; 106: 67-71. [CrossRef]

20. McCoombes JA, Hirst LW, Isbell GP. Sliding conjunctival flap for the treatment of primary pterygium. Ophthalmology 1994; 101: 169-73. [CrossRef]

21. Eksteen J, Stulting AA, Nel M. Rotational conjunctival flap surgery reduces recurrence of pterygium. S Afr Med J 2010; 100: 726-7.

22. Uçakhan $\bigcirc \bigcirc$, Kanpolat A. Combined 'symetrical conjuctival flap transpositon' and intraoperative low-dose mitomycin $\mathrm{C}$ in the treatment of primary pterygium. Clin Experiment Ophthalmol 2006; 34: 219-25. [CrossRef]

23. Mutlu FM, Sobacı G, Tatar T, Yıldırım E. A comparative study of recurrent pterygium surgery:limbal conjunctival autogreft transplantation versus mitomycin $\mathrm{C}$ with conjunctival flab. Ophthalmology 1999; 106: 817-21. [CrossRef]

24. Kim HH, Mun HJ, Park YJ, Lee KW, Shin JP. Conjunctivolimbal autograft using a fibrin adhesive in pterygium surgery. Korean J Ophthalmol 2008; 22: 147-54. [CrossRef]
25. Young $A L$, Leung GY, Cheng LL, Lam DS. A randomised trial comparing $0.02 \%$ mitomycin $C$ and limbal conjunctival autograft after excision of primary pterygium. Br J Ophthalmol 2004; 88: 995-7. [CrossRef]

26. Ivekovic R, Mandic Z, Saric D, Sonicki Z. Comparative study of pterygium surgery. Ophthalmologica 2001; 215: 394-7. [CrossRef]

27. Gris O, Guell JL, Del Campo Z. Limbal-conjunctival autograft transplantation for the treatment of recurrent pterygium. Ophthalmology 2000; 107: 270-3. [CrossRef]

28. Tananuvat N, Martin T. The results of amniotic membrane transplantation for primary pterygium compared with conjunctival autograft. Cornea 2004; 23: 458-63. [CrossRef]

29. Manning CA, Kloess PM, Diaz D, Yee RW. Intraoperative mitomycin in primary excision. A prospective, randomized trial. Ophthalmology 1997; 104: 844-8. [CrossRef]

30. Solomon A, Pires RTF, Tseng SCG. Amniotic membrane transplantation after extensive removal of primary and recurrent pterygia. Ophthalmology 2001; 108: 449-60. [CrossRef] 